\title{
Using Technological Tools to Boost Motivation and Interest in Students Studying Marathi as a Foreign Language - A Case Study in Mauritius
}

\author{
Dwintee Bye Rama, Goonesh Kumar Bahadur* \\ Centre for Innovative Life Learning (CILL), University of Mauritius, Reduit, Mauritius
}

\author{
Email address: \\ g.bahadur@uom.ac.mu (G. K. Bahadur) \\ ${ }^{*}$ Corresponding author
}

\section{To cite this article:}

Dwintee Bye Rama, Goonesh Kumar Bahadur. Using Technological Tools to Boost Motivation and Interest in Students Studying Marathi as a Foreign Language - A Case Study in Mauritius. International Journal of Education, Culture and Society. Vol. 2, No. 6, 2017, pp. $208-212$. doi: $10.11648 /$ j.ijecs.20170206.18

Received: November 28, 2016; Accepted: January 10, 2017; Published: January 10, 2018

\begin{abstract}
In Mauritius, it was found that students find it hard to learn the foreign language in Marathi which is an optional language. The main reasons were that these students do not have outside exposure to the language after school classes; they learn and practice the language only in their classroom. Moreover, since the subject is being taught though the traditional teaching method, students were not motivated. The researchers have observed that many students failed in this subject. Thus for this research project, NVU Composer freeware was used to develop the learning content on the topic 'weather' in Marathi Language for students in their fourth year of study at primary school ( 8 to 9 years old). The implementation of the learning tool in Marathi was carried out in a class comprises of 18 students. The ARCS model of motivational design was used to design the learning lesson using NVU Composer. For evaluation purposes, i-Spring Quiz Maker was used in the form of multiple choices questions and true and false questions. Many activities were included in the learning lesson such as recorded audio, viewing videos, reading activities, and designing covers for a story in Marathi Language and completing a story in writing sentences in Marathi. The assessments would cater for the three types of learners namely Kinesthetic, Visual and Auditory learners. The results from the assessments showed a slight improvement and students showed more interest in the subject.
\end{abstract}

Keywords: Marathi Language, Technology, Freeware, Types of Learners, Motivation

\section{Introduction}

The technological era is where almost everyone is using technological devices anywhere and anytime. Technology is a facilitating tool for education where teachers and students benefit from it. Al-Mahrooqi \& Troudi stated that today's language teachers need to learn how to take advantage of technologies and how to integrate them into their teaching [1]. The use of technological tools is considered to be essential as learners can easily acquire the four basic skills in language; listening, speaking, reading and writing. The Marathi language is one among the Asian languages that is being taught in Mauritius as a foreign language. Learners have difficulties to grasp the language, thus they cannot read or write properly. As learners have not been properly exposed to the language since an earlier age and little social interaction, this resulted in insufficient acquisitions of the language. Moreover we note that learners are not well exposed to these optional languages as learning takes place only in the classroom. Both learners and educators do not make an effort to move beyond the boundaries of textbook. According to Gendreau, the problem associated with language textbook is that they do not reflect the reality i.e. there is very little resemblance to how people talk in real life [2]. Thus it leads to boredom as learners are repeatedly exposed to the same scene. Another factor affecting the proper acquisition of the optional languages is the fact that at home students are not exposed to such language. Rhodes (cited by Hwang Lynch, 2011) encourages parents to make their children more aware of languages around them [3]. She believes it is important to start the conversation with kids about how interesting other languages are. 
This study was carried out in a school in a rural region in the south east area of the island. The aim was to use different technological tools to enhance the learning of Marathi language in the classroom. It has been observed that the students are not motivated to learn the language despite various teaching aids made available to them in their classes.

In Mauritius, in the primary schools, the learners learn different foreign languages and are classify as follows:

- Compulsory languages: English, French

- Optional languages: Hindi, Urdu, Telegu, Tamil, Mandarin and Marathi.

One approach to teaching a foreign language is to get the students into the context, therefore leading to learn the language rapidly through the repeated exposure called the process of assimilation. In the $21^{\text {st }}$ century, the education sector is trying to make use of technological devices to teach foreign languages as it is a language which is completely unfamiliar to its surrounding and to gain attention. According to Altun, he stated that using technology in foreign language classes is both beneficial for the students and teachers [4]. Educators have the tendency to use this tool to motivate and to make the subjects more interesting. Over the past ten years, internet, smart phones, computers played an eminent role in our daily life. Similarly using technological tools in foreign language has been a great contribution. Cetto mentioned that "as per his experience, technology has broadened the spectrum of interactive while empowering the student's learning process by providing better opportunities for language usage" [5]. Technology provides opportunities for interaction, allows for immediate feedback, increases the autonomy of the learner; stimulates real life situations and experiences through video, audio, and graphics. Learning tool is considered as an aid to help learners in an effective way. Those tools help students to move from abstract to semi concrete or concrete approach and facilitate the learning process. Thus for this research project, NVU Composer freeware was used to develop the learning content on the topic 'weather' for students in their fourth year of study at primary school (8 to 9 years old).

The ARCS model of motivational design created by Keller was used to design the learning lesson using NVU Composer [6]. It consists of four main areas:

- Attention- Arouse student curiosity and interest.

- Relevance - Relate to student's experience and needs.

- Confidence - Scaffold student's success of meaningful tasks.

- Satisfaction - Build student's sense of reward and achievement

The aim of designing and developing the learning resources was to construct interest in learners and make them eager to learn Marathi language as a modern approach. This learning resource would be easily accessible on any personal computer, laptop and on tablet. To use the learning tool, the learners should have notion of click button and how to go on next page. Internet is required only for viewing live videos.

For evaluation purposes, i-Spring Quiz Maker was used. It is an online interactive tool that allows users to design quiz, drag-n-drop questions, audio, video and equations. With iSpring Quiz Maker, interactive quiz can be published to any SCORM compliant LMS in flash or HTML format. For the summative evaluation, the learners will be assessed using MCQ questions and True or False questions. Feedback will be given to them after answering each question. In some MCQ question, images will be used as supports, especially catering for visual learners. The following model was used to design and implement the learning tools:

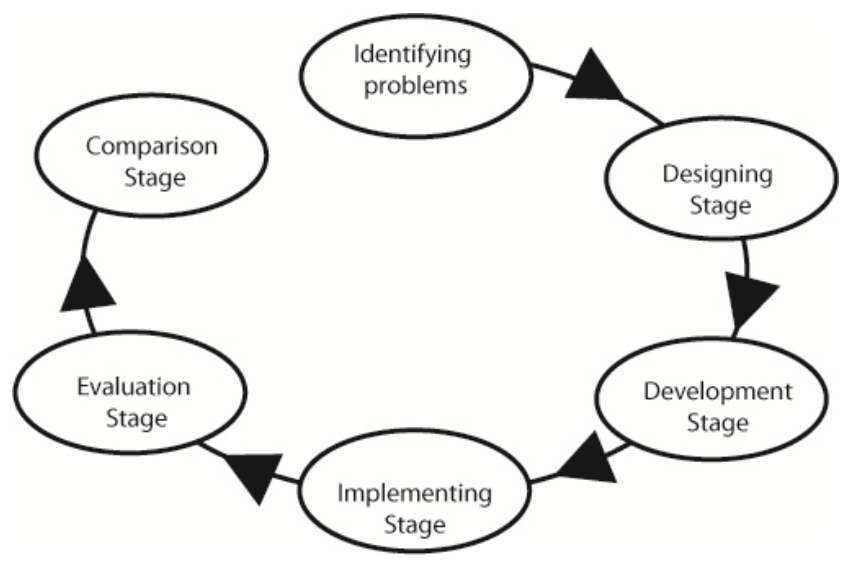

Figure 1. Stages in designing and developing the learning tools.

\section{Methodology}

The implementation of the learning tools in Marathi was carried out in a class comprises of 18 students. It constituted of four high flyers, eight average learners and six slow learners. The eight average learners had little difficulties in understanding the contents. However, the six slow learners needed special attention as they needed a lot of consolidation work. One was still unfamiliar with the Marathi alphabets. To have a concordant results on measuring whether using technological tools would be more beneficial for Marathi class, the class of 18 students was divided into two groups, Team A and Team B, and each team consisted of 9 pupils. There was an equal distribution of learners in both groups.

Table 1. Number of pupils participating.

\begin{tabular}{lllll}
\hline & $\begin{array}{l}\text { Number of } \\
\text { pupils }\end{array}$ & $\begin{array}{l}\text { High } \\
\text { flyers }\end{array}$ & $\begin{array}{l}\text { Average } \\
\text { learners }\end{array}$ & $\begin{array}{l}\text { Slow } \\
\text { learners }\end{array}$ \\
\hline Using Learning Tool & 9 & 2 & 4 & 3 \\
Traditional Approach & 9 & 2 & 4 & 3 \\
\hline
\end{tabular}

Team A received instruction by using the traditional approach. The teacher would use questioning strategies to build from their prior knowledge. Then they would use pictures for discussion purposes. The students were asked to read the text aloud. Formative assessment will involve students to work out the questions in their school's textbooks. Summative evaluations would consist of two activities as follows:

- The children were requested to complete a story in Marathi, thus making use of the imagination and creativity. 
- Learners would have to design a cover for the story. They would make use of their creativity to design the front cover for their story and were free to choose any materials they wish to use.

Team B would receive instructions and be assessed using technologies. The implementation would be conducted in the ICT room and in the Marathi class. Each child would be allocated a computer to explore the learning tool on 'Weather' developed in Marathi. On each computer the programme Google IME, Marathi font was installed. To type in Marathi language, the learners would need to convert the English font to Marathi and open their Ms Word to type. A pre-training section was given to all learners on Google IME prior to the start of the lesson. It is to be noted that these learners already have prior knowledge of using a computer and are computer literate.

To build from their prior knowledge, a small video on 'weather' was shown to the students. After which, the teacher would proceed with the explanation of the story. Next, they would be listening to a recorded audio of the story and proceed with the reading activity. This audio would help them to work out the activities. Formative assessment involves students to work out the questions using the Quiz Maker I-spring. Summative evaluations would consist of two activities as follows:

- The children are requested to complete a story in Marathi, thus making use of imaginative thinking and creativity. The teacher would act as a facilitator and guide the students. Then the learners had to save their drafts on pen drives and project them on interactive whiteboard. Each learner would read aloud their finishing part of their story.

- For the last activity, students were asked to design a front cover for the lesson on 'Weather'. They were free to choose how they wish to design their covers and present them in front of the class.

The learners were assessed by the following criteria in the table below.

Table 2. Assessment Criteria.

\begin{tabular}{|c|c|c|c|c|}
\hline \multicolumn{5}{|l|}{ Assessment Criteria } \\
\hline Criteria & Excellent & Good & Satisfactory & Poor \\
\hline $\begin{array}{l}\text { Make flexible use of learning } \\
\text { tool to work all activities }\end{array}$ & Work out all the activities & $\begin{array}{l}\text { Work out all the activities but } \\
\text { some partially done }\end{array}$ & $\begin{array}{l}\text { Work out } 1 \text { activity with some } \\
\text { mistake }\end{array}$ & $\begin{array}{l}\text { Could not work } \\
\text { any activities }\end{array}$ \\
\hline $\begin{array}{l}\text { Think creatively to complete } \\
\text { the end of the story in their } \\
\text { own way }\end{array}$ & $\begin{array}{l}\text { To express their ideas, think } \\
\text { creatively and write a good } \\
\text { sentence structure with } \\
\text { vocabularies }\end{array}$ & $\begin{array}{l}\text { To express their ideas, think } \\
\text { creatively and having } \\
\text { essential elements of a } \\
\text { sentence structure }\end{array}$ & $\begin{array}{l}\text { To express their ideas, some } \\
\text { parts are not adequately } \\
\text { connected with the other } \\
\text { elements }\end{array}$ & $\begin{array}{l}\text { Cannot complete } \\
\text { the ending part of } \\
\text { the story }\end{array}$ \\
\hline $\begin{array}{l}\text { Effective use of resources } \\
\text { provided. Ms Word to type in } \\
\text { Marathi language }\end{array}$ & Type well without any mistake & Type but 2-3 typing mistakes & Not Type properly & $\begin{array}{l}\text { Could not type } \\
\text { well }\end{array}$ \\
\hline Originality of the story & Completely original ideas & $\begin{array}{l}\text { Some ideas/scripts taken } \\
\text { from another story }\end{array}$ & $\begin{array}{l}\text { Most ideas copied from another } \\
\text { story }\end{array}$ & $\begin{array}{l}\text { Did not complete } \\
\text { the story }\end{array}$ \\
\hline $\begin{array}{l}\text { Creativity and originality of } \\
\text { front cover }\end{array}$ & Very creative and unique ideas & $\begin{array}{l}\text { Somewhat unique and } \\
\text { creative ideas }\end{array}$ & Not creative and unique ideas & $\begin{array}{l}\text { Cannot create a } \\
\text { front cover. }\end{array}$ \\
\hline Presentation of front cover & $\begin{array}{l}\text { Present it very confidently with } \\
\text { good intonation and justifying }\end{array}$ & $\begin{array}{l}\text { Present it very confidently } \\
\text { with good intonation }\end{array}$ & $\begin{array}{l}\text { Present it but look confidence } \\
\text { and intonation }\end{array}$ & $\begin{array}{l}\text { Cannot perform } \\
\text { this task }\end{array}$ \\
\hline
\end{tabular}

\section{Results and Analysis}

Completing the story-Using Word/ Google IME

The aim of this activity was that the learner applied the $21^{\text {st }}$ Century skills for the first activity. They needed to think creatively to be able to complete the story and type in Marathi using Microsoft Word and changing the font mode into Google IME.

Creating a cover

To design the cover, students were free to use any materials such as coloured papers to represent their ideas. There were no barriers or limits concerning using imagination and creativity. While expressing themselves they were developing their speaking skills in the Marathi language and gain confidence. Robinson mentioned that creativity is as important in education as literacy and both should be treated with the same status [7]. As a 21st century skill, successful individuals are those who have creative thinking skills. When it comes to creativity, one of the biggest concerns is usually how we can be more creative, or come up with better ideas.
Creative thinking has an important role and has to be developed at the earliest stage.

Comparison of Traditional Approach with Technology Approach

Table 3. Results obtained for both Traditional and Technology Approaches.

\begin{tabular}{llll}
\hline \multicolumn{3}{l}{ Traditional approach Using Learning Tool } \\
\hline Pupils Index No & Marks (100) & Pupils Index & Marks (100) \\
\hline NB1 & 73 & NB10 & 80 \\
NB2 & 77 & NB11 & 96 \\
NB3 & 89 & NB12 & 96 \\
NB4 & 34 & NB13 & 79 \\
NB5 & 50 & NB14 & 79 \\
NB6 & 81 & NB15 & 87 \\
NB7 & 50 & NB16 & 70 \\
NB8 & 46 & NB17 & 41 \\
NB9 & 47 & NB18 & 70 \\
Mode $=50$ & \multicolumn{3}{|c}{ Mode $=70,79,96$} \\
Mean $=60.7$ & \multicolumn{3}{c}{ Mean $=77.6$} \\
Median $=50$ & \multicolumn{3}{c}{ Median $=79$} \\
\hline
\end{tabular}




\section{Comparison of total scores Traditional v/s Technology Based}

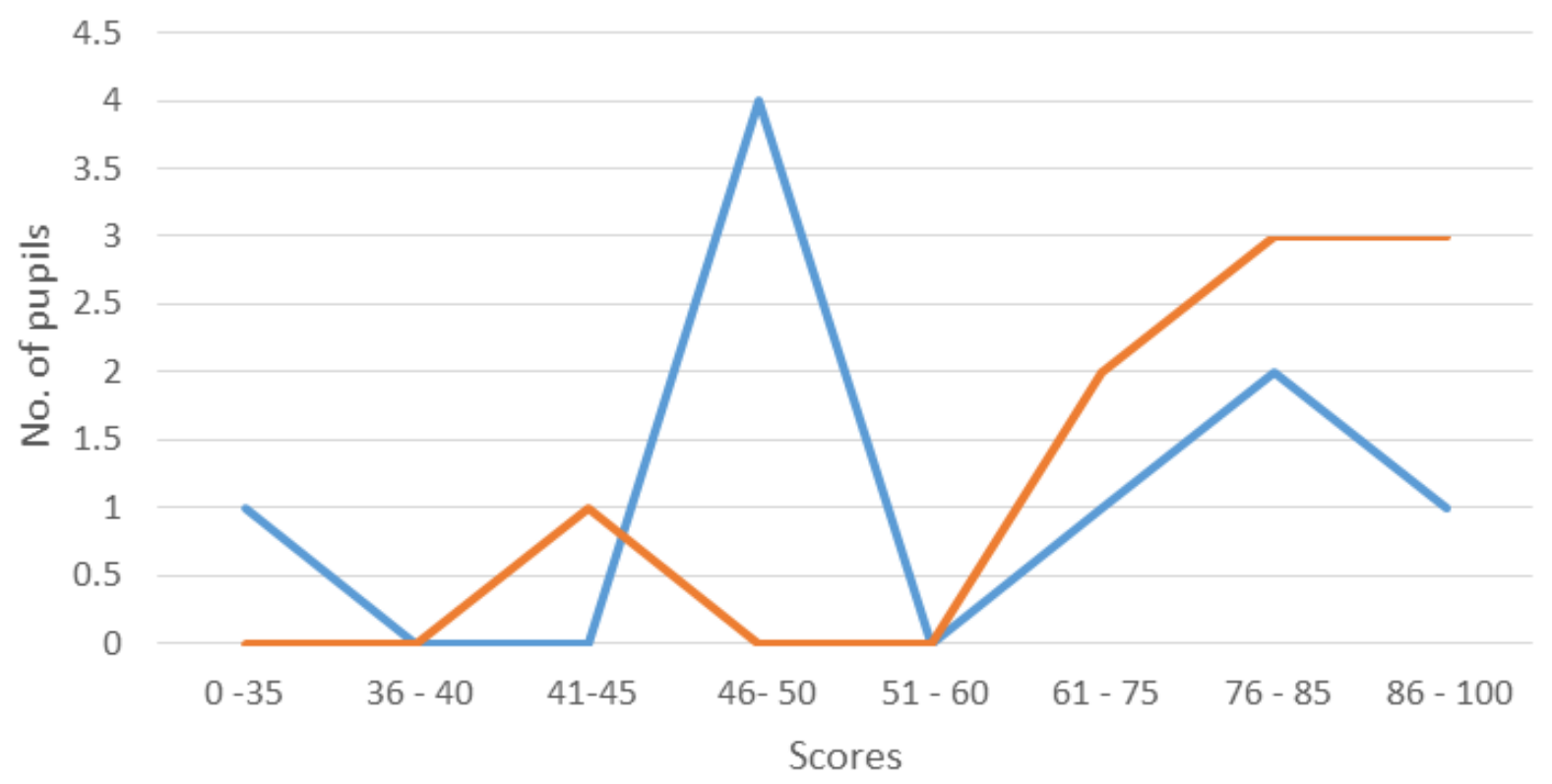

-Traditional Approach - Technology Based Approach

Figure 2. Comparison of total scores.

After analyzing the graph in Figure 2, we observe that using technological tools in the foreign language classroom is really effective. It is to be noted that the majority of students studying in the traditional group have received marks between 40 to 50 marks. However the majority of students studying under the technology based have received between 60 to 80 marks. Slow learners have also succeeded in passing the subject in team B. Altun stated that after analyzing the findings of his project, similar results were obtained for foreign language [8]. With technology, he recorded a $16.16 \%$ improvement. The aim of his study was to investigate the contribution of technology-based instruction to development of language skills. Altun stated that there were not great difference between students who advocate traditional methods and those who advocate technology-based instruction [9].

Thus from the data analyzed after the implementation, the researchers found that there is a difference of $12 \%$ from traditional to technology based, which means that using technological tools in the foreign language is indeed effective. From the results obtained, we have been able to observe that the students were more at ease using technological tools to learn Marathi language rather than the traditional way. There is a good significant improvement between traditional to the technology approach. The assessments would cater to the three types of learners.

Kinesthetic learners:

Individuals that are kinesthetic learn best with and active "hands-on" approach. These learners favour interaction with the physical world. Most of the time kinesthetic learners have a difficult time staying on target and can become unfocused effortlessly [10]. The hands on approach in these activities involved manipulating the device by doing the drag and drop and type the story into Marathi language.

Visual learners:

Visual learners think in pictures and learn best in visual images. They depend on the instructor's or facilitator's nonverbal clues such as body language to help with understanding. Sometimes, visual learners favour sitting in the front of the classroom. They also take descriptive notes over the material being presented [11]. In the formative evaluation it would be done by observing the pictures and wordings.

\section{Auditory learners:}

These individuals discover information through listening and interpreting information by the means of pitch, emphasis and speed. These individuals gain knowledge from reading out loud in the classroom and may not have a full understanding of information that is written [12]. In the lessons it would be by the reading activity and by listening to the recorded voice that helped them to work out those activities. For the multiple questions and true or false questions, they were suited to all level of learners. They needed to tackle all the questions within a lapse of time. Feedbacks were provided to each student after each question. 
Table 4. Activities related to ARCS

\begin{tabular}{|c|c|c|}
\hline & Elements in Learning Resources related to ARCS & Comments/ observations \\
\hline Attention & A welcoming note was included & $\begin{array}{l}\text { Learners felt thrilled and were eager to discover this } \\
\text { lesson. }\end{array}$ \\
\hline Relevance & $\begin{array}{l}\text { Listening of the recorded voice of the story. Explanation of the rules of the reading } \\
\text { activity where pupils need to pick a friend at random to continue reading. Learners } \\
\text { will become aware that they have an important role to play within the activity and } \\
\text { finally this activity gives everyone the opportunity to participate in the reading }\end{array}$ & $\begin{array}{l}\text { There was a complete silence in the class when the } \\
\text { learners were listening to the story. They were happy } \\
\text { as well as everyone in the class have been given the } \\
\text { opportunity read with help or without help. }\end{array}$ \\
\hline Confidence & $\begin{array}{l}\text { Learners came in front and related the story with its finishing part which they have } \\
\text { typed in Marathi, by reading it aloud with confidence. Created a font cover for the } \\
\text { story afterwards by using their creativity }\end{array}$ & $\begin{array}{l}\text { Many learners have been able to break their shyness } \\
\text { by coming in front of the class. Learners were able to } \\
\text { read with confident. }\end{array}$ \\
\hline Satisfaction & $\begin{array}{l}\text { Designing a cover for the lesson. Learners were given opportunity to unleash their } \\
\text { imaginative skills and make drawings (front cover of the story book). It was also a } \\
\text { way a make it fun for children as they like drawing and coloring They were free to } \\
\text { use any materials to create their cover. They shared their cover and their creativity } \\
\text { with their peer. And explained why they created it this way. }\end{array}$ & $\begin{array}{l}\text { Learners were creative and created an original cover. } \\
\text { Each cover was different and they have been able to } \\
\text { express themselves through the cover making. They } \\
\text { found it fun and really enjoyed this activity. }\end{array}$ \\
\hline
\end{tabular}

\section{Conclusion}

This project demonstrated that educational technology tools can be used for the teaching and learning purpose of Marathi as a foreign language. The results from the study even showed that using the NVU and the Quiz Maker as technological tools created a positive impact on learners' performance, they were more interested and very much motivated in the foreign language class.

In this study, the learning tool was based on the lesson on 'Weather' and it was targeted to the 8 to 9 years old learners of a government school in Mauritius. They have been able to grasp and understand the lesson in the Marathi language. The learning tool was created in such a way that the teacher can present the lesson in a more attractive manner, thus helping the learners to better visualize the concept and listen as well. Using the learning tool brought a change in the class; the learners could assimilate all the required information easily. Learning was considered as fun for the learners. It promotes peer learning; as during the process of evaluation, they were helping each other from the start of the reading activity to creating a front cover using their imagination.

Educators should be more sensitize of the technological era where digital natives indeed need technological learning tools to understand the learning process. They should be aware that these tools support their teaching and enhance learner's learning. There should be more encouragement to use learning tools in foreign language classes; this will encourage learners to learn. Learning language is an important factor as it develops our listening, speaking, reading and writing skills, it is a life time process and stepping out from primary school they will keep on learning language. Therefore it is surely a wise move to help them to enjoy the language class.

\section{References}

[1] Al-Mahrooqi. R \& Troudi. S. 2014. Using Technology in Foreign Language Teaching. 1st ed. 12 Back Chapman Street, Newcastle upon Tyne, NE6 2XX, UK: British Library Cataloguing in Publication Data.

[2] Gendreau S. 2012. How to remember words when learning a language. Lingholic. Available at:http://www.lingholic.com/how-to-remember-words-whenlearning-a-language/.

[3] Hwang Lynch G. 2011. Ways to Introduce Your Kids to Foreign Languages. Reading and Languages.

[4] Available at: http://www.pbs.org/parents/readinglanguage/articles/introduce -kids-to-foreign-language.html.

[5] Griffiths J, Podirsky M, Deakin S \& Maxwell S. 2002. "Children are learning environments". Available at: http://ehlt.flinders.edu.au/education/DLiT/2002/environs/suyi $\mathrm{n} /$ homepg.html.

[6] Altun M. 2015. The integration of technology into foreign language teaching International Journal on New Trends in Education and Their Implications. 6 (1), 22-26. Available at: http://www.ijonte.org/FileUpload/ks63207/File/03a.altun.pdf.

[7] Cetto M. 2010. Technology and second language teaching. Brujula, (8), 119-121.

[8] Keller J M. 2009. Motivational design for learning and performance: The ARCS model approach. Springer Science \& Business Media.

[9] Robinson K. 2011. Out of Our Minds: Learning to be Creative. Capstone Publishing Ltd, United Kingdom.

[10] 11. 12. Ldpride.net. 2008. Understanding your learning style. Available from: http://www.aultmancollege.edu/ Files/Understanding-Learning-Styles.pdf. 